\section{Hambatan Komunikasi dalam Perkuliahan Daring pada Masa Pandemi Covid-19}

Lontar: Jurnal Ilmu Komunikasi, 2021

Vol. 9(2), 2021

Copyright (C2021, Abdul Malik

This is an open access article under the CC-BY-SA

license

DOI: $10.30656 /$ lontar.v9i2.4037

Article History

Submission: November $21^{\text {th }}, 2021$

Revised: December 6th,2021

Accepted: December 21th, 2021

\author{
Abdul Malik \\ Universitas Serang Raya \\ Email: Kangdoel2002@gmail.com
}

\begin{abstract}
This study was conducted to obtain an overview of the communication barriers between lecturers and students during the online class in Covid-19 pandemic. The methode used in this research is a case study and descriptive qualitative in which the result obtained from the research and the processed of the data about the communication barriers that occur in online lectures are deeply processed. The collected data consists of primary data that is obtained from online interview and discussion with informan. Secondary data is obtained from various literature sources related to information and policies online lectures. Based on the result of research, shown that at least there are three communication barriers that take place in online lectures, namely technological, environmental, and psychological barriers. Those three barriers are considered as lecture processed disruptions which implicate that there are students' difficulties in studying and understanding the lecture material well.
\end{abstract}

Keywords: Communication Barriers, Online Lectures, Technology Barriers, Environmental Barriers, Psychological Barriers

\begin{abstract}
Abstrak
Penelitian ini dilakukan untuk memperoleh gambaran tentang hambatan komunikasi yang dialami oleh dosen dengan mahasiswa dan mahasiswa dengan mahasiswa dalam perkuliahan daring pada masa pandemi Covid-19. Metode yang digunakan dalam penelitian ini adalah studi kasus dan bersifat kualitatif deskriptif di mana di dalamnya dipaparkan hasil perolehan dan olah data secara mendalam tentang hambatan komunikasi yang terjadi dalam perkuliahan daring. Adapun data yang dikumpulkan terdiri dari data primer yang diperoleh melalui tanya jawab dan diskusi secara daring dengan informan. Sedangkan data sekunder diperoleh dari berbagai sumber literatur yang berkaitan dengan informasi dan segala kebijakan terkait perkuliahan secara daring. Berdasarkan hasil penelitian, diketahui bahwa setidaknya terdapat tiga hambatan komunikasi yang berlangsung dalam perkuliahan daring, yakni hambatan teknologi, hambatan lingkungan, dan hambatan psikologi. Ketiga hambatan itu dianggap mengganggu proses perkuliahan, yang berimplikasi pada kesulitan mahasiswa mengikuti dan memahami materi perkuliahan dengan baik.
\end{abstract}

Kata Kunci: Hambatan Komunikasi, Perkuliahan Daring, Hambatan Teknologi, Hambatan Lingkungan, Hambatan Psikologi. 


\section{PENDAHULUAN}

Pandemi Covid-19 telah berlangsung hampir dua tahun dan hingga kini belum diketahui sampai kapan akan berakhir. Kondisi ini tentu saja menyebabkan terjadinya perubahan besarbesaran dalam tata kehidupan sosial kita. Bukan saja dalam interaksi kita yang kini menjadi begitu berbatas, tetapi juga berimplikasi pada berbagai aspek lainnya, termasuk dalam aspek pendidikan.

Sejak diumumkan bahwa virus corona covid-19 ini masuk ke Indonesia pada Februari 2020 silam, pemerintah kemudian mengambil kebijakan terkait dengan pembatasan mobilitas sosial sebagai antisipasi untuk menahan laju persebaran virus tersebut. Mulai dari Pembatasan Sosial Berskala Besar atau PSBB hingga Perberlakuan Pembatasan Kegiatan Masyarakat (PPKM).

Salah satu point kebijakan pembatasan itu juga terkait dengan persoalan di lingkup pendidikan. Antara lain diatur lebih spesifik dalam Surat Edaran Menteri Pendidikan dan Kebudayaan Republik Indonesia No. 3 Tahun 2020 tentang Pencegahan Corona Virus Disease (Covid-19) Pada Satuan Pendidikan, termasuk Surat Kepala LLDIKTI Wilayah IV Nomor: 1685/LL4/TU/2020 tentang Himbauan Antisipasi Penyebaran Virus Corona (Kementerian Pendidikan dan Kebudayaan Indonesia, 2020; LLDIKTI, 2020).

Demikian pula Universitas Serang Raya (Unsera). Mengacu pada kebijakan tersebut, melalui Surat Keputusan Rektor Nomor 229/01.04/UNSERA/III/2020, Unsera terhitung sejak awal Maret 2020 hingga Juni 2021 telah mengubah pola perkuliahan dari sebelumnya bersifat tatap muka atau luar jaringan (luring) menjadi dalam jaringan (daring). Jikapun dilakukan secara tatap muka terbatas pada perkulihan bersifat praktikum dengan jumah peserta dan waktu pertemuan yang dibatasi serta harus sesuai dengan protokol kesehatan yang ketat (Rektor Universitas Serang Raya, 2020).

Dalam pelaksanaanya, perkuliahan daring ini dilakukan dengan memanfaatkan Learning Manajemen System (LMS) bernama Spada Unsera. Melalui LMS tersebut dosen pengampu mata kuliah mengunggah materi kuliah, baik bersifat teks maupun bersifat audio visual untuk kemudian diunduh dan dipelajari oleh mahasiswa. Melalui LMS itu pula mahasiswa mengisi absensi. Agar perkuliahan berlangsung interaktif, dosen biasanya memanfaatkan aplikasi lain untuk mendukung LMS tersebut, antara lain aplikasi Zoom dan Google Meet karena bersifat interactivity. Graham (dalam Nasrullah, 2013) menyebut bahwa karakteristik interactivity merupakan salah satu cara yang berjalan di antara pengguna dan mesin (teknologi) dengan memungkinkan para pengguna maupun perangkat yang saling terhubung secara interaktif.

Namun demikian, tetap saja dalam praktiknya perkuliahan yang berlangsung secara daring kerap dihadapkan oleh berbagai kendala. Baik bersifat teknis maupun non teknis. Kendalakendala tersebut sejatinya juga telah banyak dikupas dalam sejumlah penelitian oleh para peneliti di berbagai perguruan tinggi. Hariyanti, Mun'im, \& Hidayat (2020), misalnya, dalam penelitiannya menyebut bahwa hambatan yang dialami dalam perkuliahan yang berlangsung secara daring antara lain hambatan fisik, psikis, faktor tenaga pengajar, fasilitas, keluarga, dan kegiatan lain. Sedangkan Nugroho, Wati, \& Dianastiti (2020), berdasarkan penelitiannya berhasil mengidentifikasi kendala perkuliahan secara daring, antara lain bahwa dibandingkan dengan perkulihan secara luring, perkuliahan secara daring belum cukup efektif dan banyak menimbulkan distorsi oleh sebab perangkat perkuliahan yang belum mendukung, termasuk dosen yang kesulitan untuk menyampaikan metode perkulihan secara daring yang mengakibatkan sulitnya mahasiswa memahami materi yang disampaikan.

Selain kendala-kendala sebagaimana di atas, sejatinya terdapat kendala lain yang menjadi faktor penghambat kelancaran perkuliahan daring, yakni kendala atau hambatan komunikasi, baik komunikasi antara dosen dengan mahasiswa, maupun mahasiswa dengan mahasiswa. Noise, atau hambatan komunikasi dapat berupa gangguan seperti suara, persepsi yang tidak sama, atau misinterpretasi yang dapat mengubah arti dari pesan yang disampaikan. Hambatan komunikasi ini tentu saja menjadi persoalan krusial dalam perkuliahan. Sebab, perkuliahan yang baik sehingga diperoleh hasil sebagaimana diharapkan erletak pada proses dan praktik komunikasi yang terjalin selama perkuliahan berlangsung. Hambatan komunikasi juga dapat memengaruhi 
kondusivitas perkuliahan yang berimplikasi pada semangat tidaknya baik dosen ataupun mahasiswa dalam melaksanakan dan mengikuti perkuliahan. Dalam hal ini Devito (2011) mendefinisikan hambatan komunikasi sebagai segala sesuatu yang dapat mendistorsi pesan, hal apapun yang menghalangi penerima menerima pesan. Hambatan-hambatan tersebut dapat berlangsung dalam semua konteks atau situasi komunikasi. DeVito juga membagi hambatan komunikasi pada tiga hal, yakni hambatan secara fisik, hambatan secara psikologis, dan hambatan secara semantik.

Sementara Effendy (2017) menyebut empat faktor penghambat dalam komunikasi. Pertama, hambatan sosiologis, antropologis, dan psikologis. Hambatan sosiologis ini berkaitan erat dengan persoalan hubungan sosial seperti status sosial, gtinhgkat pendidikan, dan sebagainya yang dapat menjadi hambatan dalam berkomunikasi. Hambatan antropologis berkaitan erat dengan persoalan antropolgis seperti ras, agama, kebiasaan, norma, dan sebagainya yang memengaruhi proses komunikasi. Hambatan psikologi berkaitan dengan persoalan psikologi seperti perasaan sedih, prasangka, shock culture, dan sebagainya yang bisa menimbulkan hambatan berkomunikasi. Kedua, hambatan semantik atau bahasa. Hambatan bahasa ini umumnya terjadi ketika apa yang disampaikan oleh komunikator dipahami berbeda oleh komunikan akibat bahasa yang tidak dimengerti atau komunikator salah ucap, dan hal-hal yang berkaitan dengan kebahasaan lainnya. Ketiga, hambatan mekanis. Hambatan ini muncul akibat penggunaan media dalam berkomunikasi yang menimbulkan berbagai kendala teknis sehingga berimplikasi pada terganggunya proses komunikasi. Keempat, hambatan ekologis. Disebut juga hambatan lingkungan oleh sebab gangguan komunikasi itu muncul dari lingkungan di mana komunikasi itu berlangsung.

Selanjutnya, untuk mengetahui bagaimana hambatan komunikasi itu berlangsung dalam perkuliahan daring pada masa Pndemi Covid-19 dan faktor-faktor apa saja yang menyebabkan terjadinya hambatan komunikasi tersebut, maka penulis berinisiatif melakukan kajian lebih lanjut. Adapun yang menjadi subjek penelitian adalah mahasiswa yang mengikuti perkuliahan daring yang diampu oleh peneliti sendiri di dua kelas berbeda dengan mata kuliah yang sama, yakni Komunikasi untuk Perubahan Sosial dan Pembangunan pada Program Studi Ilmu Komunikasi Universitas Serang Raya.

Penelitian sejenis terkait dengan tema penelitian ini pernah dilakukan oleh Vera (2020), berjudul Strategi Komunikasi Dosen dan Mahasiswa dalam Meningkatkan Kualitas Pembelajaran Daring selama Pandemik Covid-19. Berdasarkan penelitian tersebut diketahui bahwa dalam pembelajaran daring perlu dibuat strategi komunikasi secara khusus dengan tujuan untuk mengurangi gegar budaya dan tingkat kejenuhan, antara lain melalui optimalisasi penggunaan media pembelajaran, intensitas komunikasi yang berlangsung dua arah, serta partisipasi aktif mahasiswa selama perkuliahan berlangsung. Penelitian lain adalah yang dilakukan oleh Wowor \& Putri (2021), tentang Efektivitas Komunikasi dalam Perkuliahan Online terjhadap Proses Belajar pada Mahasiswa Manokwari Papua Barat. Dari hasil penelitian tersebut diketahui bahwa komunikasi yang efektif menjadi pendung berlangsungnya perkuliahan secara daring secara baik dan optimal.

Bagi penulis, kedua penelitian di atas bisa dijadikan sebagai referensi dari penelitian yang penulis lakukan. Adapun hasil penelitian ini diharapkan dapat berkontribusi dalam melengkapi berbagai penelitian yang terkait dengan pembelajaran atau perkuliahan daring pada masa pandemi Covid-19, utamanya di bidang kajian komunikasi, sehingga dapat diperoleh bukan saja pemahaman, tetapi juga menjadi solusi yang komprehensif dalam menghadapi berbagai hambatan yang terjadi dalam pembelajaran/perkulihan daring, baik pada masa Pandemi Covid19 maupun pada masa setelahnya.

\section{METODE PENELITIAN}

Penelitian ini menggunakan pendekatan kualitatif dengan metode studi kasus. Creswell (2013) menyebut pendekatan kualitatif sebagai upaya untuk melakukan eksplorasi dan memahami makna yang oleh sejumlah individu atau sekelompok sosial dianggap berasal dari 
masalah sosial atau kemanusiaan. Sedangkan Stake (dalam Creswell, 2013), mengatakan bahwa metode studi kasus merupakan strategi penelitian di mana di dalamnya peneliti menyelidiki secara cermat suatu program, peristiwa, aktivitas, proses, atau sekelompok individu. Kasus-kasus dibatasi oleh waktu dan aktivitas, dan peneliti mengumpulkan informasi secara lengkap dengan menggunakan berbagai prosedur pengumpulan data berdasarkan waktu yang telah ditentukan.

Penelitian tentang Hambatan Komunikasi dalam Perkuliahan Daring pada Masa Pandemi Covid-19 ini sesuai dengan karakteristik kajian studi kasus karena secara metodologi memenuhi unsur sebagaimana dikemukakan oleh Yin (2019), yaitu; (1) Peneliti memiliki informasi yang sedikit tentang hal yang diteliti; (2) Fokus penelitian adalah sebuah fenomena yang telah berlangsung, serta: (3) ada banyak sumber data.

Adapun yang menjadi subjek penelitian adalah mahasiswa yang mengikuti perkuliahan daring Tahun Akademik 2020/2020 Genap yang diampu oleh peneliti sendiri di dua kelas berbeda dengan mata kuliah yang sama, yakni Komunikasi untuk Perubahan Sosial dan Pembangunan pada Program Studi Ilmu Komunikasi Universitas Serang Raya, kelas A1 dan A2. Selain itu, penelitian ini menggunakan dua data penelitian, yaitu data yang bersifat primer dan data yang bersifat sekunder. Data yang bersifat primer didapat berdasarkan observasi partisipan selama perkuliahan serta hasil diskusi dan tanya jawab yang dilakukan melalui WhatsApp Group (WAG) masing-masing kelas. Sementara data yang bersifat sekunder diperoleh dari kajian pustaka dan berbagai literatur yang mendukung penelitian ini.

\section{HASIL DAN PEMBAHASAN}

Perkuliahan yang berlangsung secara daring tentu saja sangat berbeda situasinya jika dibandingkan dengan perkuliahan secara luring. Dari hasil observasi dan diskusi dengan mahasiswa peserta perkuliahan daring, mereka umumnya merasakan bahwa perkuliahan secara luring jauh lebih efektif dibanding dengan perkuliahan daring. Selain itu, perkuliahan luring juga memungkinkan terjalinnya interaksi yang baik, baik mahasiswa dengan mahasiswa maupun mahasiswa dengan dosen. Demikian pula sifat komunikasinya, dapat berlangsung dua arah sehingga dapat memudahkan mahasiswa untuk lebih memahami materi kuliah yang disampaikan dosen. Jika pun ada yang tidak atau belum dipahami, mahasiswa dapat bertanya langsung atau meminta penjelasan lebih lanjut.

Dengan kata lain, interaksi dan komunikasi dalam perkuliahan bersifan luring dianggap oleh mahasiswa lebih efektif, dan efektivitas komunikasi ini merupakan salah satu faktor penentu keberhasilan perkuliahan itu sendiri. Maka, semakin efektif komunikasi yang terjalin antara dosen dengan mahasiswa maupun mahasiaswa dengan mahasiswa, maka perkuliahan pun akan berjalan dengan baik. Tubss dan Moss (dalam Mulyana, 2019) menyebut bahwa komunikasi bisa dikatakan efektif manakala orang berhasil menyampaikan apa yang dimaksudkannya, atau komunikasi dinyatakan efektif jika rangsangan yang disampaikan atau dimaksudkan oleh pengirim atau sumber, berkaitan erat dengan rangsangan yang ditangkap dan dipahami oleh penerima. Masih menurut Tubss dan Moss (dalam Rakhmat, 2019), komunikasi yang efektif paling tidak akan menimbulkan lima hal, yakni, pengertian, kesenangan, pengaruh pada sikap, hubungan yang kian baik, serta tindakan.

Sebaliknya dengan perkuliahan bersifat daring. Meskipun menggunakan aplikasi seperti Zoom atau Google Meet yang memungkinkan terjalinnya interaksi sebagaimana interaksi dalam perkuliahan bersifat luring, tetapi mahasiswa dihadapkan dengan berbagai hambatan komunikasi, sehingga perkuliahan tidak berlangsung optimal, dan hal tersebut tentu saja memengaruhi tingkat pemahaman mahasiswa terhadap materi yang disampaikan dosen.

Berdasarkan hasil wawancara diketahui bahwa hambatan komunikasi yang terjadi dalam perkuliahan daring ini terpetakan pada faktor-faktor berikut ini.

\section{1) Hambatan/Faktor teknologi.}

Faktor teknologi atau disebut juga hambatan teknis dianggap sebagai hambatan paling utama dalam perkuliahan secara daring. Selain merasa belum terbiasa menggunakan teknologi komunikasi untuk kuliah, mahasiswa juga merasa mengalami apa yang disebut gagap teknologi. 
Sehingga, di awal-awal perkuliahan berlangsung mereka merasa kebingungan tentang bagaimana cara menggunakan teknologi komunikasi tersebut, mulai bagaimana menginstal aplikasi Zoom atau Google Meet di ponsel maupun di komputer, bagaimana cara mengoperasikannya, hingga hal-hal bersifat teknis lainnya.

Faktor ketidakkebiasaan dan kegagapan ini pada akhirnya berpengaruh terhadap interaksi dan komunikasi yang berlangsung selama perkuliahan. Pada masa-masa awal perkuliahan, mahasiswa kesulitan untuk menyimak materi yang disampaikan dosen karena tidak atau belum tahu bahkan lupa mengaktifkan volume suara. Termasuk pada saat saling sapa antara dosen dan mahasiswa. Sapaan, bahkan penjelasan dosen tentang materi kuliah kerap tidak terdengar oleh karena persoalan baik ketidakstabilan jarungan ataupun keterbatasan kuota internet.

Situasi seperti itu bahkan bisa berlangsung hingga perkuliahan berakhir. Alhasil, jangankan memahami penjelasan dosen tentang materi perkuliahan yang disampaikan, mendengarkan pun tidak. Situasi yang tidak jauh berbeda juga terjadi manakala mahasiswa hendak memberikan feedback. Sejumlah mahasiswa mengakui bahwa mereka ingin bertanya kepada dosen tetapi Zoom atau Google Meet yang mereka gunakan dalam posisi unmute dan tidak tahu bagaimana mengubahnya menjadi mute.

Problem lain adalah pada suara dosen yang tidak stabil atau berdengung akibat gangguan sinyal dan gangguan teknis lainnya, termasuk juga kebocoran suara. Sejumlah mahasiswa mengaku kerap mengalami situasi gangguan di mana saat asyik menyimak penjelasan dosen, tibatiba sinyal terputus entah karena kuota internet yang telah habis atau persoalan lain, sehingga butuh waktu yang tidak sebentar untuk kembali tersambung. Karenanya, alih alih memberikan feedback berupa pertanyaan kepada dosen, untuk bisa menyimak secara jelas materi yang disampaikan pun dihadapkan berbagai kenadala. Kondisi yang tentu saja membuat situasi perkuliahan tidak berlangsung kondusif yang mengakibatkan mahasiswa tidak atau kurang memahami materi yang disampaikan.

\section{2) Faktor/Hambatan Psikologi}

Faktor psikologi ikut memengaruhi komunikasi yang terjalin selama perkuliahan daring berlangsung. Mahasiswa umumnya mengalami situasi yang aneh, terutama pada masa-masa awal perkuliahan. Melalui penggunaan aplikasi Zoom ataupun Google Meet, mereka merasakan situasi bersama dan menyatu dengan rekan satu kelas, tetapi karena termediasi oleh media teknologi, rasa kebersamaan dan kemenyatuan itu serasa hambar karena tidak menemukan situasi yang intim sebagaimana situasi luring atau tatap muka. Terhadap situasi demikian ini mahasiswa menyebutnya sebagai pertemuan dan kebersaamaan yang tanpa ikatan emosional sehingga terasa kering dan hambar.

Kenyataan tersebut secara psikologis menganggu interaksi dan komunikasi yang berlangsung. Interaksi selama perkuliahan berlangsung agak canggung, lebih bersifat mekanis, monoton, dan formal. Akibatnya, komunikasi yang terjalin lebih bersifat satu arah di mana dosen lebih dominan berkomunikasi, bahkan hingga perkuliahan usai. Jika pun terjadi dialog, waktunya tidak lama dan lebih bersifat formalitas.

Kondisi komunikasi yang apatis akibat kendala psikologis ini semakin terasa oleh mahasiswa yang biasa pasif dalam setiap perkuliahan. Baik karena tidak terbiasa maupun faktor-faktor yang lain seperti malu dan tidak percaya diri. Akibatnya, pemanfaatan aplikasi Zoom ataupun Google Meet untuk terjalinnya interaksi dan komunikasi di dalam kelas pun tidak berlangsung secara optimal dan maksimal oleh sebab kendala psikologis tersebut.

Pada sisi yang lain, mahasiswa juga merasa tidak fokus mengikuti kuliah yang menyebabkan mereka memilih pasif atau tidak responsif. Ketidakfokusan itu antara lain disebabkan oleh rasa jenuh karena berlama-lama duduk dan menghadap komputer, situasi lingkungan yang tidak kondusif, rasa malas, merasa aneh karena bicara bukan dengan orang lain melainkan dengan komputer, dan faktor-faktor psikologis lainnya. 


\section{3) Faktor/Hambatan Lingkungan}

Faktor atau hambatan lain yang memengaruhi proses komunikasi dalam perkuliahan daring adalah faktor lingkungan atau faktor ekologis. Berdasarkan wawancara, diketahui bahwa mahasiswa kerap merasa kurang mampu berkonsentrasi dalam perkuliahan karena lingkungan yang tidak mendukung. Seperti diketahui, selama perkuliahan daring, mereka umumnya berada di rumah atau di tempat-tempat di luar kampus, seperti di kos, bahkan di dalam kendaraan yang memungkinkan munculnya gangguan dari pihak lain, seperti dari anggota keluarga, teman dan orang lain. Menurut mahasiswa, situasi perkuliahan di dalam kelas dan di rumah atau tempat lain sangat berbeda jauh. Jika perkuliahan berlangsung di dalam kelas situasinya terkendali, tertib, dan kondusif. Sebaliknya saat perkuliahan daring di rumah atau tempat lain, butuh konsentrasi yang kuat karena lingkungannya yang tidak kondusif dan sangat mengganggu.

Gangguan itu terjadi mulai dari munculnya obrolan maupun suara lain akibat tempat yang dijadikan untuk melakukan zoom meeting ataupun Google Meet penuh dengan suasana keramaian ataupun tidak kondusif. Selain menyebabkan rasa enggan atau malas untuk merespon dan berkomunikasi baik dengan dosen maupun sesama mahasiswa, situasi demikian juga menimbulkan rasa malu atau tidak percaya diri untuk bertanya dan berkomunikasi lebih lanjut karena khawatir jadi bahan tontonan orang-orang yang berada di rumah.

Pada sisi lain, ketika mahasiswa mendapatkan tempat yang jauh lebih bisa fokus mengikuti perkulihan semisal di kamar atau ruangan lain. Tetapi, lagi-lagi gangguan lingkungan itu tetap muncul, yaitu terbawa suasana kamar atau ruangan yang membuat mudah mengantuk, malas, merasa tidak serius kuliah, dan sebagainya.

Kondisi-kondisi yang demikian itu, selain mengganggu konsentrasi kuliah juga mengakibatkan kesulitan tersendiri dalam menjalin komunikasi, baik dengan sesama rekan kuliah maupun dengan dosen, semisal memberikan tanggapan ataupun sebatas untuk bertanya.

\section{KESIMPULAN}

Berdasarkan pembahasan sebagaimana di atas, pada akhirnya dapat disimpulkan bahwa hambatan komunikasi yang terjadi dalam perkuliahan pada masa Pandemi Covid-19 menjadi salah satu faktor utama tidak berlangsungnya perkuliahan secara optimal. Hambatan komunikasi itu disebabkan oleh tiga faktor utama, yaitu faktor teknologi, faktor psikologi, dan faktor lingkungan. Oleh karena itu, sebagai langkah perbaikan dan demi terselenggaranya perkulihan daring yang lebih baik dan sesuai dengan tujuan pembelajaran, faktor-faktor yang menjadi hambatan komunikasi ini perlu menjadi perhatian serius, antara lain penting dibuat metode khusus bagaimana dosen, khususnya, mampu menjalin interaksi dan komunikasi yang baik selama perkuliahan sehingga mahasiswa mampu bersikap proaktif dan responsif.

Hal lain adalah faktor teknologi. Karena bersifat teknis namun cukup mengganggu proses komunikasi, maka perlu segera diatasi. Kampus antara lain perlu meningkatkan kapasitas jaringan internet dan infrastruktur pendukung lainnya sehingga dapat mengakomodir kepentingan perkulihan secara daring. Sedangkan bagi mahasiswa, perlu meningkatkan kesadaran tentang situasi perkuliahan daring yang mungkin akan berlangsung lama, sehingga dengan sendirinya kendala-kendala bersifat teknis tersebut dapat diprediksi dan diatasi. 


\section{DAFTAR PUSTAKA}

Creswell, J. W. (2013). Research Design Pendekatan Kualitatif, Kuantitatif, dan Mixed (Terjemahan). Yogyakarta: Pustaka Pelajar.

Devito, J. (2011). Komunikasi Antar-Manusia; Kuliah Dasar . Jakarta: Karisma Publishing. Effendy, O. U. (2017). Ilmu Komunikasi Teori dan Praktek. Bandung: Remaja Rosdakarya.

Hariyanti, D., Mun'im, A. H., \& Hidayat, N. (2020). Identifikasi Hambatan Mahasiswa dalam Pelaksanaan Pembelajaran Biologi secara Daring Selama Masa Pandemi Covid-19 di Kabupaten Jember. ALVEOLI: Jurnal Pendidikan Biologi, 1(1), 11-21.

Kementerian Pendidikan dan Kebudayaan Indonesia. Surat Edaran Menteri Pendidikan dan Kebudayaan Republik Indonesia No. 3 Tahun 2020 tentang Pencegahan Corona Virus Disease (Covid-19) Pada Satuan Pendidikan. , (2020).

LLDIKTI. Surat Kepala LLDIKTI Wilayah IV Nomor: 1685/LL4/TU/2020 tentang Himbauan Antisipasi Penyebaran Virus Corona. , (2020).

Mulyana, D. (2019). Ilmu Komunikasi: Suatu Pengantar. Bandung: Remaja Rosdakarya.

Nasrullah, R. (2013). Cyber Media. Yogyakarta: IDEA Press.

Nugroho, S. A., Wati, A. F., \& Dianastiti, F. E. (2020). Kendala dan Solusi Pembelajaran Daring di Perguruan Tinggi (Constraints and Solutions in the Implementation of Online Lesson in Higher Education). Jalabahasa, 16(2), 196-205.

Rakhmat, J. (2019). Psikologi Komunikasi (Edisi Revisi). Bandung: Simbiosa Rekatama Media.

Rektor Universitas Serang Raya. Surat Keputusan Rektor Nomor 229/01.04/UNSERA/III/2020 tentang Pelaksanaan Kerja secara Daring. , (2020).

Vera, N. (2020). Strategi Komunikasi Dosen Dan Mahasiswa Dalam Meningkatkan Kualitas Pembelajaran Daring Selama Pandemic Covid-19. Avant Garde, 8(2), 165-177.

Wowor, H. A. F., \& Putri, K. Y. S. (2021). Efektivitas Komunikasi dalam Perkuliahan Online terhadap Proses Belajar pada Mahasiswa Manokwari Papua Barat. Jurnal Komunikasi Pendidikan, 5(1), 79-92.

Yin, R. K. (2019). Studi Kasus, Desain dan Metode. Jakarta: PT. Raja Grafindo Perkasa. 